development on vesicular-arbuscular mycorrhizae and endogonaceaous spore population in field-grown vegetable crops. I. Summer-grown crops. New Phytol. 79:341-348.

Saif, S.R. 1981. The influence of soil aeration on the efficiency of vesicular-arbuscular mycorrhizae. I. Effect of soil oxygen on the growth and mineral uptake of Eupatorium odoratum L. inoculated with Glomus macrocarpus New Phytol. 88:649-659.

Saif, S.R. 1983. The influence of soil aeration on the efficiency of vesicular-arbuscular mycorrhizas: I. Effect of soil oxygen on growth and mineral uptake in Eupatorium odorarum L., Sorghum bicolor (L.) Moench and Guizotia abyssinica (L. f.) Cass. inoculated with vesicular-arbuscrdar mycorrhizal fungi. New Phytol. 95:405417
Sanders, F.E. 1975. The effect of foliar-applied phosphate on the mycorrhizal infections of onion roots, p. 261-276. In: F.E. Sanders, B. Mosse, and P.B. Tinker (eds.). Endomycorrhizas. Academic, London.

Scott, A.J. and M. Knott. 1974. A cluster analysis method for grouping means in the analysis of variance. Biometrics 30:507-512.

Smith, S. E., B. J. St John, F.A. Smith, and D.J.D. Nicholas. 1985. Activity of glutamine synthetase and glutamate dehydrogenase in Trifolium subterraneum L. and Allium cepa L.: Effects of mycorrhizal infection and phosphate nutrition. New Phytol. 99:211-227.

Stamps, R.H. and C.R. Johnson. 1984. Vesiculararbuscular mycorrhizal inoculation and fertilizer level affect yield, morphology, chlorophyll content, water uptake and vase life of leatherleaf fern fronds. Proc. Fla. State Hort. Soc. 97:264-266.

Steel, R.G.D. and J.H. Torrie. 1980. Principles and procedures of statistics. a biometrical approach. McGraw Hill, New York.

Stolzy, L. H., J. Letey, T.E. Szuszkicwicz, and O.R. Lunt. 1961. Root growth and diffusion rates as function of oxygen concentration. Soil Sci. Soc. Amer. Proc. 25:463-465.

Sutton, J.C. 1973. Development of vesicular-arbuscular mycorrhizae in crop plants. Can. J. Bet. 51:2487-2493.

Warncke, D.D. 1980. Recommended test procedure for greenhouse growth media, p. 31-33. North Dakota State Univ., Fargo. North Central Reg. Publ. 221, Bul. 499.

\title{
Constant Soil Temperature Influences Flowering of Alstroemerias
}

\author{
Theo J. Blom ${ }^{1}$ and Brian D. Piott ${ }^{2}$ \\ Horticultural Research Institute of Ontario, Vineland Station, Ont., \\ LOR 2E0, Canada
}

Additional index words. rhizome, soil cooling, soil heating

\begin{abstract}
The effect of constant $16 \mathrm{C}$ and noncontrolled soil temperature on flowering of four Alstroemeria cultivars grown in a greenhouse was studied over 3 years. Soil temperature regime did not influence either the start or cessation of flowering. During spring/summer, production was $15 \%$ lower under constant soil temperature, irrespective of cultivar. During fall/winter, the effect of constant soil temperature was cultivardependent; yield of 'Red Sunset' was increased by $150 \%$, while that for 'Rio' decreased by 2270 relative to the noncontrolled. Annual production was not affected, but the ratio between the production of spring/summer and fail/winter decreased from 3.1 to 2.2 for noncontrolled and constant soil temperature, respectively.
\end{abstract}

Alstroemeria has developed worldwide importance as a cut flower crop due to excellent vase life, low energy growing requirement, and high productivity. Rhizomes are normally planted October through December in northern-latitude greenhouses. Production commences the following MarchApril and continues until June-July, when rhizomes cease to flower and produce primarily Vegetative shoots. A fall flush can be expected during October-November at lat. $56^{\circ} \mathrm{N}$ (Powell and Bunt, 1986; Vonk Noordegraaf, 1975a). This cropping pattern usually continues for 2 to 4 years.

The control of flowering is biphasic (Wilkins et al., 1980; Vonk Noordegraaf, 1981). Plants require a cold induction treatment (thermophase) as a prerequisite to flowering. This can be fulfilled by a short (4-week) pe-

received for publication 3 Oct. 1988. Project H86-2002. ICAR 86000243. We gratefully acknowledge the support of Flowers Canada. The cost of publishing this paper was defrayed in part by the payment of page charges. Under postal regulations, this paper therefore must be hereby marked advertisement solely to indicate this fact.

${ }^{1}$ Research Scientist.

${ }^{2}$ Agricultural Technician. riod at $5 \mathrm{C}$ or by progressively longer periods at higher (16 weeks at 13C) temperatures (Healy and Wilkins, 1982). Relatively high soil temperatures $(17 \mathrm{C})$ have also been shown to induce flowering (Vonk Noordegraaf, 1975b), while 22C stops flowering (Healy et al., 1982). The mechanism that triggers a flush once the thermtophase has been fulfilled is still unclear. However, exposure to a longday regime (photophase) induces earlier flower production than short days (Heins and Wilkins, 1979), but does not always increase total production (Vonk Noordegraaf, 1975b). Cessation of flowering after a flush is believed to be due to high soil temperatures, lack of plant growth substances (Heins and Wilkins, 1979; Healy and Wilkins, 1982), and/or long photoperiod (Healy and Wilkins, 1985).

Our study investigated the effects of soil temperature, maintained at an inductive level year-round, on start and cessation of flowering and total production. Flower production of four alstroemeria cultivars was compared using an uncontrolled and a constant $16 \mathrm{C}$ soil temperature year-round over 3 years.

Two adjoining $50-\mathrm{m}^{2}$ computer-controlled glass greenhouses, each with four ground beds, were used. The soil of one compartment was maintained at $16 \mathrm{C}$ set-point yearround by mixing and circulating either cold or warm water through 18-mm-diameter polybutylene lines; the soil temperature in the other compartment was not controlled. Soil temperatures were recorded at $15-\mathrm{cm}$ depth using "T" thermocouples and a Kaye Digistrip datalogger (Bedford, Mass.). In both compartments, bed areas were mulched with polystyrene beads, and the pathways were covered with straw. Air temperature was set according to commercial practices at a min-

Table 1. Annual yields in marketable stems $/ \mathrm{m}^{2}$ for noncontrolled (NST) and constant (CST) soil temperature during two seasons averaged over 3 years.

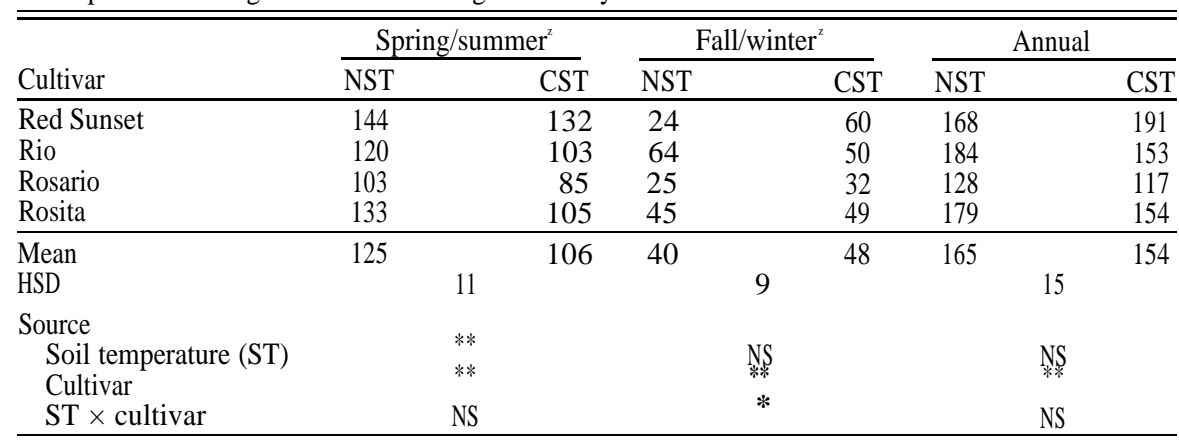

${ }^{2}$ Spring/summer (1 Apr.-30 Sept.); Fall/winter (1 Oct.-31 Mar.).

, *,** Nonsignificant or significant at $P=0.05$ or 0.01 , respectively. 

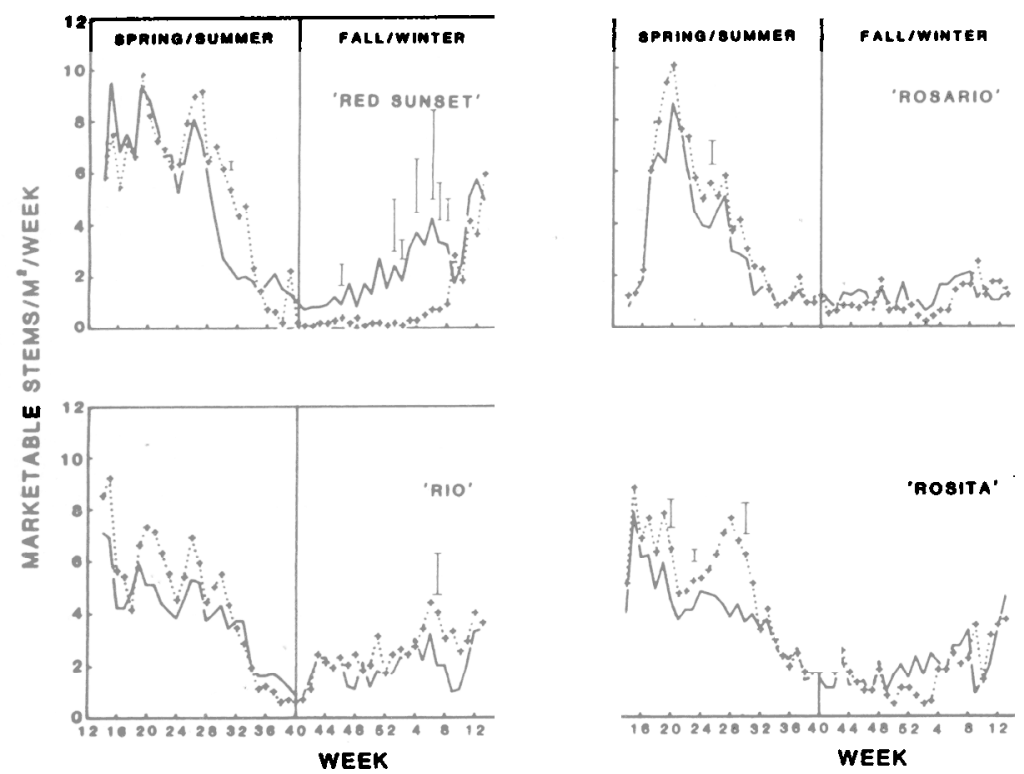

Fig. 1. Weekly marketable yield for four alstroemeria cultivars for a constant (-) 16C or a noncontrolled $(+\cdots+)$ soil /temperature averaged over 3 years. LSD is indicated by vertical bar only when significant $(P<0.05)$.

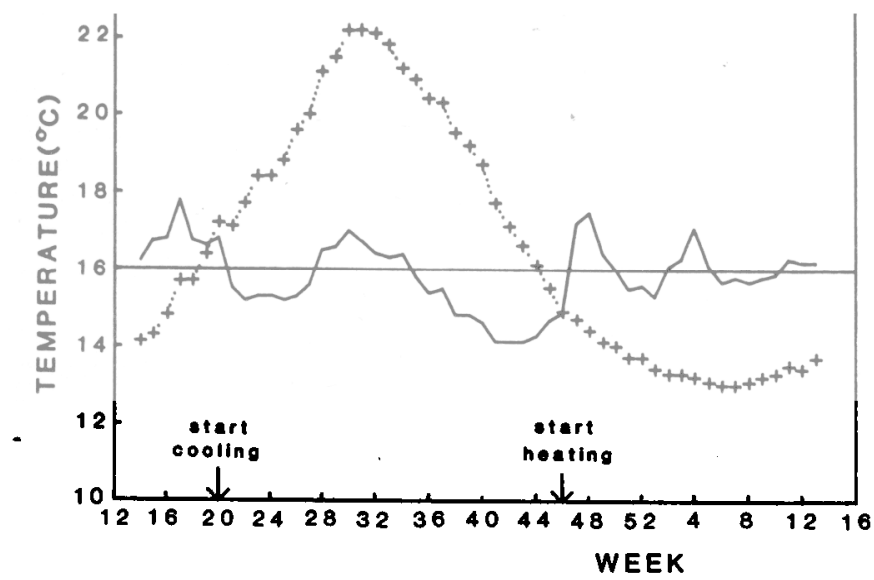

Fig. 2. The weekly soil temperature for constant (-: CST) and noncontrolled $(+\cdots+$ : NST) soil \{temperature measured at $15-\mathrm{cm}$ depth. Each point is average of 21 days, with $\mathrm{CST}=15.9 \mathrm{C}, \mathrm{SD}=$ $1.4 ; \mathrm{NST}=16.6 \mathrm{C}, \mathrm{SD}=3.2$.

imum $13 / 12 \mathrm{C}$ (day/night) and ventilation at 16C. Natural daylength was extended to 13 hr between September and April using incandescent lights at an irradiance of 2.3 $\mu \mathrm{mol} \cdot \mathrm{s}^{-1} \cdot \mathrm{m}^{-2}$.

Four cultivars representing three breeding lines or types were planted: 'Red Sunset' and 'Rosita' (Carmen type), 'Rosario' (butterfly type), and 'Rio' (orchid type). Rhizomes were planted in Nov. 1984 at a depth of $15 \mathrm{~cm}$ with 36 plants of one cultivar per ground bed (sandy loam), providing a gross spacing of 2.9 plants $/ \mathrm{m}^{2}$.

Flowering pattern. Marketable flowers were harvested and recorded weekly for 3 consecutive years starting 1 Apr. 1985 (week 14). The main flowering (Fig. 1) occurred during weeks 15-16 for 'Red Sunset', 'Rio', and 'Rosita' and $\approx 5$ weeks later for 'Rosario'. This pattern was independent of soil temperature, but consistent for 3 consecutive years. The flushing continued on a cyclical basis (5-8 weeks), with a sharp decline after weeks 26-28. This sharp decline was also consistent for 3 consecutive years and independent of soil temperature, refuting the proposition that high soil temperatures (20C) cause cessation of flowering (Healy and Wilkins, 1985, 1986; Heins and Wilkins, 1979). After the sharp decline, the flowering pattern was not affected by the soil temperature, except for 'Red Sunset', which showed a higher yield from the constant than from the noncontrolled soil temperature during January and February (i.e., weeks 1-8) (Fig. 1). A small increase in production during weeks 6-8 was evident for all cultivars, but independent of soil temperature. The main spring flush started at weeks 14-16 (8 weeks later) for 'Red Sunset', 'Rio', and 'Rosita', suggesting that radiation sum has an important impact on the spring flush.
Production. Flower yields were analyzed on a cumulative seasonal basis, spring/summer (1 Apr.-30 Sept.) and fall/winter (1 Oct.31 Mar.), using Micro-SAS in a split-plot analogy. In the model, the variables "Year" and "Soil Temperature" were the main plot factors, with "Cultivars" as the subplot variable. The total number of marketable stems/ $\mathrm{m}^{2}$ was used as the dependent variable. During spring/summer, the constant soil temperature yield was $15 \%$ (average of all cultivars) less than the noncontrolled (Table 1). During the fall/winter there was no significant effect of soil temperature; however, there was a significant soil temperature $\mathrm{x}$ cultivar interaction. 'Red Sunset' produced $150 \%$ more, while 'Rio' produced $22 \%$ less under constant soil temperature. 'Rosita', a 'Regina' mutant (Broerties and Verboom. 1974), did not respond to-soil cooling during the summer, as was reported for 'Regina' (Lin, 1984).

On an annual basis, neither total production (Table 1) nor average soil temperature (Fig. 2) differed for the two soil temperature treatments. However, there is a shift in the seasonal production pattern. The ratio of the total production between spring/summer and fall/winter changed from 3.1 to 2.2 for the noncontrolled and the constant soil temperature regimes, respectively.

Although soil temperature does not affect starting and cessation of flowering, there is a quantitative effect of the soil temperature on the number of flowering shoots in the subsequent flowering period. Soil heating to $16 \mathrm{C}$ during the winter is not a viable proposition, while the effects of soil cooling to $16 \mathrm{C}$ during the summer depends on the cultivar. Different temperature response exists even within a breeding line ('Red Sunset' vs. 'Rosita'). Further research should be directed towards determining which internal (sugars, hormones) and external factors (air temperature, day length, irradiance) are responsible for flowering so that the process can be manipulated.

\section{Literature Cited}

Broertjes, C. and H. Verboom. 1974. Mutation breeding of Alstroemerias. Euphytica 23:39-44.

Healy, W.E. and H.F. Wilkins. 1982. The interaction of temperature on flowering of Alstroemeria 'Regina'. J. Amer. Soc. Hort. Sci. 107:208-251

Healy, W.E. and H.F. Wilkins. 1985. Alstroemeria, p. 419-424. In: A.H. Halevy (cd.). Handbook of flowering. vol. 1. CRC Press, Boca Raton, Fla.

Healy, W.E. and H.F. Wilkins. 1986. Relationship between rhizome temperature and shoot temperatures for floral initiation and cut flower production of Alstroemeria 'Regina'. J. Amer. Soc. Hort. Sci. 111(1):94-97.

Healy, W. E., H.F. Wilkins, and M. Celusta. 1982. The role of light quality, photoperiod and supplemental lighting on flowering of Alstroemeria 'Regina'. J. Amer. Soc. Hort. Sci. 107:10461049 .

Heins, R.D. and H.F. Wilkins. 1979. Effect of soil temperature and photoperiod on vegetative and reproductive growth of Alstroemeria 'Regina'. J. Amer. Soc. Hort. Sci. 104(3):359365. 
Lin, W.C. 1984. The effect of soil cooling and high intensity lighting on flowering of Alstroemeria 'Regina'. HortScience 19(4):515-516.

Powell, M.C. and A.C. Bunt. 1986. The effects of propagation date on flower production in $\mathrm{Al}$ stroemeria 'Campfire' and 'Red Sunset'. Scientia Hort. 28:147-157.

Vonk Noordegraaf, C. 1975a. Alstroemeria: Belichting bij 'Orchid', p. 15. In: Bloemisterij on- derzoek in Nederland, Aalsmeer, The Netherlands.

Vonk Noordegraaf, C. 1975b. Temperature and daylength requirements of Alstroemeria. Acts Hort. 51:267-274.

Vonk Noordegraaf, C. 1981. Bloemproduktie bij Alstroemeria 'Walter Fleming'. PhD Diss., Agr. Univ., Wageningen, The Netherlands.
Wilkins, H. F. W.E. Healy, and T.L. GilbertsonFerriss. 1980. Comparing and contrasting the control of flowering in Alstroemeria 'Regina', Freesia $\times$ hybrids and Lilium longiflorum, $\mathrm{p}$. 51-63. In: C. Brickell, D.F. Cutter, and M. Gregord (eds.). Petaloid monocotyledous, horticultural and botanical research. Academic, New York.

\title{
Temperature Requirements for Seed Germination of Three Penstemon Species'
}

\author{
Phil S. Allen' and Susan E. Meyer \\ Utah Division of Wildlife Resources, USDA Forest Service Intermountain \\ Research Station, Shrub Sciences Laboratory, 735 N. 500 East, Provo, \\ UT 84606
}

Additional index words. Penstemon eatonii, Penstemon palmeri, Penstemon strictus, perennials, seed dormancy, stratification, wildflowers

Abstract. To determine optimum germination temperatures and effective dormancybreaking procedures, field-grown (1983-85) seeds of 'Bandera' Rocky Mountain penstemon (Penstemon strictus Benth), 'Cedar' Palmer penstemon (Penstemon palmeri Gray), and firecracker penstemon (Penstemon eatonii Gray) were subjected to various cold stratification and incubation temperature treatments. Increased germination following an 8-week stratification occurred in seed lots containing dormant seeds, but a 2-week stratification generally failed to break dormancy. Older (1983) seeds of 'Bandera' and 'Cedar' penstemon germinated to full viability without stratification. All species showed a marked decrease in germination percentage above $20 \mathrm{C}$; $15 \mathrm{C}$ consistently produced maximum germination after 4 weeks. At $15 \mathrm{C}$, mean times to $90 \%$ of total germination were 11, 22, and 29 days for 'Bandera', 'Cedar', and firecracker penstemon, respectively. Transfer of seeds failing to germinate at warm temperatures ( 25 and $30 \mathrm{C})$ to $15 \mathrm{C}$ and applying $720 \mu \mathrm{M}$ gibberellic acid $\left(\mathrm{GA}_{3}\right)$ solution was effective in breaking primary dormancy of firecracker penstemon and secondary dormancy of 'Bandera' penstemon. Our findings suggest that incubation below 20C, combined with 8 weeks of stratification or the use of after-ripened seed, may improve seed propagation efforts for these species.

Widespread interest in perennials and in wildflowers for use as low-maintenance ornamental has increased marketing opportunities for native plants (Aimone, 1986; Allen, 1985; Cox and Klett, 1984; Gilbert, 1987; Otteson, 1986). Unfortunately, seed dormancy resulting in poor or sporadic germination can discourage growers from supplying desirable plant materials to the public (Aimone, 1986). For such species, information on germination requirements, seed age

Received for publication 7 Mar. 1989. This research was supported in part by Pittman-Robertson Federal Aid to Wildlife Project W82-R and by funds provided by the Utah Dept. of Agriculture. The cost of publishing this paper was defrayed in part by the payment of page charges. Under postal regulations, this paper therefore must be hereby marked advertisement solely to indicate this fact.

'Current address: Dept. of Horticultural Science, Univ. of Minnesota, St. Paul, MN 55108. effects on viability and dormancy, and effective dormancy-breaking procedures would benefit seed propagation efforts.

Penstemon spp. offer considerable potential for increased horticultural use. There are more than 250 perennial species of native North American penstemons (Cronquist et al., 1984), a few of which are currently cultivated (Kelaidis, 1986). While seed dormancy occurs in this genus, few reports on germination have been published (Atwater, 1980; Cox and Klett, 1984; Maguire and Overland, 1959; Salac and Hesse, 1975; Salac and Traeger, 1982).

In this study, we compared laboratory germination characteristics for successive yearly harvests of three penstemon species recently brought into field cultivation for seed production: 'Bandera' Rocky Mountain penstemon (Hooks and Oaks, 1982), 'Cedar' Palmer penstemon (Stevens and Monsen, 1988), and firecracker penstemon. In particular, the effects of cold stratification and of incubation temperature on laboratory germination rate and percentage were investigated.

Eight seed lots were obtained from producers during Sept. -Nov. 1985 (Table 1) and stored in paper containers in the laboratory $(\approx 22 \mathrm{C})$. Seeds had been held in warehouse storage by producers. The experiments described were conducted between Jan. and June 1986.

Viability for each seed lot was determined using tetrazolium staining (Grabe, 1970; Kitchen, 1988). Two 50-seed replications were imbibed on moist blotters for $12 \mathrm{hr}$, pierced with a needle, and immersed in a $1 \%$ $(\mathrm{w} / \mathrm{v})$ solution of buffered tetrazolium chloride. After $48 \mathrm{hr}$, seeds were bisected longitudinally and examined under a dissecting microscope. Seeds with embryos stained completely red were classed as viable; remaining seeds were classed as nonviable.

Two germination experiments were conducted. Treatments consisted of four replications of 50 seeds each, incubated on two

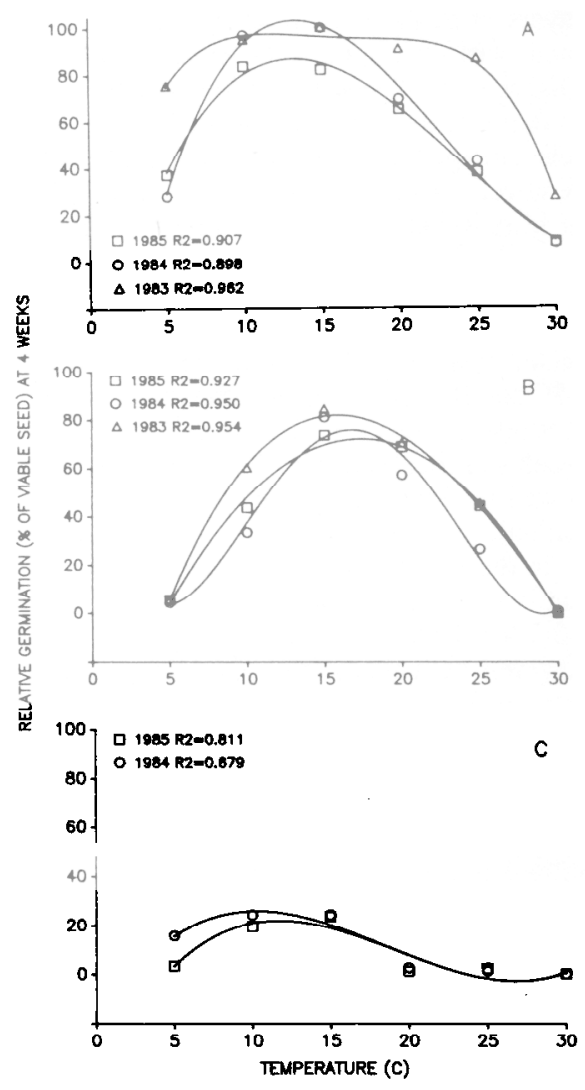

Fig. 1. Effect of temperature on seed germination of (A) 'Bandera', (B) 'Cedar', and (C) firecracker penstemon. Curves represent fitted polynomial equations $(P<0.001)$ for each seedlot. 